\title{
Anurans of the Serra do Caraça, southeastern Brazil: species composition and phenological patterns of calling activity
}

\author{
Marco A. S. Canelas ${ }^{1} \&$ Jaime Bertoluci² \\ 1. Departamento de Zoologia, Instituto de Ciências Biológicas, Universidade Federal de Minas Gerais, Av. Antonio Carlos, 6627, 31270- \\ 901 Belo Horizonte, MG, Brazil. \\ 2. Departamento de Ciências Biológicas, Escola Superior de Agricultura "Luiz de Queiroz", Universidade de São Paulo, Av. Pádua Dias, 11, \\ 13418-900 Piracicaba, SP, Brazil. (bertoluc@esalq.usp.br). Corresponding author.
}

\begin{abstract}
Annual patterns of calling and breeding activity of 38 anuran species were studied at Serra do Caraça, an 11,233 ha reserve located in a contact zone between Cerrado and Atlantic forest at the southern Espinhaço range, southeastern Brazil. Five patterns were evident: (1) species that call year-round or nearly year-round with larger aggregations generally observed in the rainy months, (2) species with opportunistic calling activity associated with rainfall during the wettest months of the year, (3) winter species, (4) explosive breeders with intense calling activity triggered by heavy rains during the rainy season or only in the beginning of the rainy season, and (5) summer species with variable breeding seasons. Both the monthly number of species with calling males and the monthly number of species that showed the maximum class of calling males were positively correlated with both mean monthly temperature and monthly precipitation.
\end{abstract}

KEYWORDS. Anurans, breeding phenology, Atlantic rainforest, montane meadows, southeastern Brazil.

RESUMO. Anuros da Serra do Caraça, sudeste do Brasil: composição de espécies e padrões sazonais de atividade vocal. Estudamos os padrões anuais de atividade vocal e reprodutiva de 38 espécies de anuros da Serra do Caraça, uma reserva de 11.233 ha localizada na zona de contato entre o Cerrado e a Mata Atlântica na porção sul da Cadeia do Espinhaço, Minas Gerais, Sudeste do Brasil. Cinco padrões foram evidenciados: (1) espécies que vocalizaram o ano todo ou quase o ano todo com agregações maiores geralmente observadas na estação chuvosa, (2) espécies com atividade vocal oportunista associada à precipitação durante os meses mais úmidos, (3) espécies de inverno, (4) espécies com reprodução explosiva com atividade vocal disparada por chuvas intensas durante a estação chuvosa ou apenas no início dessa estação e (5) espécies de verão com temporadas de vocalização variáveis. O número de espécies vocalmente ativas e o número de espécies que apresentaram agregações máximas de machos ativos mostraram-se positivamente correlacionados tanto com a temperatura média mensal como com a precipitação mensal acumulada.

PALAVRAS-CHAVE. Anura, fenologia reprodutiva, Mata Atlântica, campos rupestres, sudeste do Brasil.

Exogenous factors as rainfall and temperature strongly influence anuran breeding activity both in temperate (e.g. SALVADOR \& CARRASCAL, 1990; RitKe $e t$ al., 1992) and tropical regions (AICHINGER, 1987; Hero, 1990; Duellman, 1995; Bevier, 1997; Bertoluci, 1998; BERTOLUCI \& RodRIGUES, 2002a). Aseasonal tropical areas often have many species that are able to reproduce throughout the year (CRUMP, 1974; Duellman, 1978). In seasonal tropical environments, however, most species reproduce during the rainy season (AICHINGER, 1987; Hero, 1990; Gascon, 1991; Duellman, 1995; Bevier, 1997; Bertoluci, 1998; Bertoluci \& Rodrigues, 2002a). Longterm studies dealing with reproductive activity patterns of Neotropical anurans from both the Atlantic rainforest and mountain meadows of southeastern Brazil in a community context are still rare (HEYER et al., 1990; Eterovick \& SAZima, 2000; Bertoluci, 1998; Bertoluci \& RODRIGUES, 2002a).

This paper describes annual patterns of calling activity of 38 anuran species from Serra do Caraça, southeastern Brazil, by monitoring calling activity of males and evidences of actual reproduction at selected breeding sites. Additionally, we provide for the first time a list of anuran species for this locality. These informations may be used as a point of departure for future evaluations of the conservation status of the populations involved, which is fundamental considering anuran declines and local extinctions suggested in the last two decades for southeastern Brazil (HEYER et al., 1988, 1990; Weygoldt, 1989; Haddad \& SAZIMA, 1992; BertoluCi \& HeYer, 1995; ETEROVICK et al. 2005).

\section{MATERIAL AND METHODS}

Field work was carried out at Reserva Particular do Patrimônio Natural Santuário do Caraça, an 11,233 ha reserve of Atlantic rainforest located in the Serra do Caraça, in the Espinhaço range, state of Minas Gerais, southeastern Brazil $\left(20^{\circ} 05^{\prime} \mathrm{S}, 43^{\circ} 28^{\prime} \mathrm{W}\right)$. The Serra do Caraça has altitudes between 900 and 2,000 m. The climate is $\mathrm{Cwb}$ of Köppen. According to data provided directly by Agência Nacional de Águas, Belo Horizonte, the average annual rainfall from 1984 to 2001 was 2,031.29 \pm $480.92 \mathrm{~mm}$. Between October 2001 and September 2002 the annual accumulated rainfall was $2,038.40 \mathrm{~mm}$ and rainfall was irregularly distributed through the year; the rainy season lasted from October to March (Fig. 1). Mean monthly temperatures for the study period are also shown in Fig. 1.

The vegetation that covers the lower parts of the Serra do Caraça are the Semideciduous Montane Atlantic forest and Cerrado; at higher altitudes montane meadow ("campo rupestre") and misty forest occur. 


\section{RESULTS}

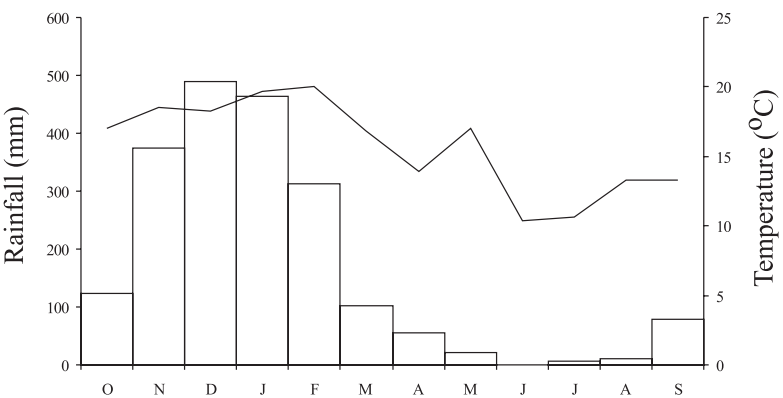

Fig. 1. Mean monthly temperature (line) and monthly rainfall at the study site between October 2001 and September 2002.

In order to determine calling and breeding seasons of anuran species, four aquatic habitats with different physiognomies were chosen for year-round monitoring. These habitats, located in open area, forest and forest edge, are as follows: Site R1 is a little stream located in montane meadow $(1,600-1,700$ m elevation). It is mainly rocky, with rocky puddles, some containing sand and dead leaves and sticks. The studied portion is $500 \mathrm{~m}$ long and, in the rainy season, mean width and mean depth were $4.51 \pm 2.29 \mathrm{~m}(0.40-8.50 \mathrm{~m})$ and $0.28 \pm 0.21 \mathrm{~m}(0.05-$ $0.90 \mathrm{~m})$, respectively $(\mathrm{n}=26$ measurements). Site $\mathrm{R} 2$ is a moderately sized stream located in the primary forest (1,250 $\mathrm{m}$ elevation). The studied portion is $280 \mathrm{~m}$ long and, in the rainy season, mean width and mean depth were $5.78 \pm 3.18 \mathrm{~m}(0.40-11.50 \mathrm{~m})$ and $0.59 \pm 0.44 \mathrm{~m}(0.20$ $-1.30 \mathrm{~m})$, respectively ( $\mathrm{n}=13$ measurements). Upstream in the studied portion, there is mainly sandy bottom backwaters and downstream there are rapids and two little waterfalls. Site L1 is a semipermanent lake $(1,200 \mathrm{~m}$ elevation, $500 \mathrm{~m}^{2}, 1 \mathrm{~m}$ deep) located at the edge of a disturbed forest; it was formed by interruption of a small stream. Site L2 is a permanent swamp (1,200 m elevation, $400 \mathrm{~m}^{2}, 0.20 \mathrm{~m}$ deep) located in open habitat.

Field work was carried out from October 2001 until September 2002. To determine patterns of calling activity of anurans, the number of calling males for each species was estimated twice a month between 18:00 h and 24:00 h at each selected site. Sites were also visited during the day to verify the occurrence of any diurnal vocalization. The following classes for the number of synchronously calling males per species at each site were established: (1) $1-2$, , (2) 3-5, (3) 6-10, (4) 11-20, (5) 21-50, (6) more than 50 (Aichinger, 1987; Bertoluci, 1998; Bertoluci \& RODRIGUES, 2002a). The calling activity of species that do not vocalize in the selected sites or in the selected portions of the sites was determined in a qualitative way. The presence of egg clutches, amplectant pairs, and gravid females were considered evidences of actual reproduction. Correlation between variables were tested using Spearman's Correlations Coefficient (ZAR, 1996). Voucher specimens were deposited in the Herpetological Collection of the Universidade Federal de Minas Gerais, Brazil(UFMG).
During this study 43 anuran species were found at Serra do Caraça (Tab. I). These species belong to eight families: Brachycephalidae (3), Bufonidae (2), Centrolenidae (2), Cycloramphidae (4), Hylidae (22), Leptodactylidae (7), Microhylidae (1), and Thoropidae (2). Table II summarizes the annual breeding patterns of 38 anuran species at the study site based on the presence of calling males and evidences of actual reproduction in

Table I. Anuran species recorded in the Serra do Caraça, southeastern Brazil, between October 2001 and September 2002.

\section{BRACHYCEPHALIDAE}

Eleutherodactylus izecksohni Caramaschi \& Kisteumacher, 1989 “1988”

Eleutherodactylus juipoca Sazima \& Cardoso, 1978

Eleutherodactylus sp. (gr. lacteus)

\section{BUFONIDAE}

Chaunus pombali (Baldissera, Caramaschi, \& Haddad, 2004)

Chaunus rubescens (Lutz, 1925)

\section{CENTROLENIDAE}

Hyalinobatrachium uranoscopum (Müller, 1924)

Hyalinobatrachium sp. (aff. eurygnatum)

\section{CYCLORAMPHIDAE}

Crossodactylus trachystomus (Reinhardt \& Lütken, 1862)

Hylodes uai Nascimento, Pombal \& Haddad, 2001

Odontophrynus cultripes Reinhardt \& Lütken, 1862

Proceratophrys boiei (Wied-Neuwied, 1824)

\section{HYLIDAE}

Aplastodiscus arildae (Cruz \& Peixoto, 1987 “1985”)

Bokermannohyla alvarengai (Bokermann, 1956)

Bokermannohyla circumdata (Cope, 1871)

Bokermannohyla martinsi (Bokermann, 1964)

Bokermannohyla nanuzae (Bokermann \& Sazima, 1973)

Dendropsophus elegans (Wied-Neuwied, 1824)

Dendropsophus minutus (Peters, 1872)

Dendropsophus seniculus (Cope, 1868)

Hypsiboas faber (Wied-Neuwied, 1821)

Hypsiboas albopunctatus (Spix, 1824)

Hypsiboas polytaenius (Cope, 1870 “1869")

Phasmahyla jandaia (Bokermann \& Sazima, 1978)

Phyllomedusa burmeisteri Boulenger, 1882

Scinax duartei (B. Lutz, 1951)

Scinax eurydice (Bokermann, 1968)

Scinax fuscovarius (A. Lutz, 1925)

Scinax luizotavioi (Caramaschi \& Kisteumacher, 1989)

Scinax machadoi (Bokermann \& Sazima, 1973)

Scinax squalirostris (A. Lutz, 1925)

Scinax sp.1 (aff. perereca)

Scinax sp.2 (gr. catharinae)

Scinax sp. 3

\section{LEPTODACTYLIDAE}

Leptodactylus bokermanni (Heyer, 1973)

Leptodactylus fuscus (Schneider, 1799)

Leptodactylus jolyi Sazima \& Bokermann, 1978

Leptodactylus ocellatus (Linnaeus, 1758)

Physalaemus cuvieri Fitzinger, 1826

Physalaemus evangelistai Bokermann, 1967

Physalaemus sp. (aff. olfersii)

\section{THOROPIDAE}

Thoropa megatympanum Caramaschi \& Sazima, 1984

Thoropa miliaris (Spix, 1824)

MICROHYLIDAE

Elachistocleis ovalis (Schneider, 1799) 
the selected breeding sites. For this summary we used the highest class of calling males obtained for all monitoring sessions per site per month. Anurans called in every month of the year, with a minimum of six species in June and a maximum of 26 species in November. Five annual patterns were evident: (1) species that call yearround or nearly year-round with larger aggregations in the rainy months; in this group, Crossodactylus trachystomus (Reinhardt \& Lütken, 1862) vocalized predominantly during the day and Hypsiboas polytaenius (Cope, 1870 "1869") vocalized in all months, and sometimes under very low temperatures (about $5^{\circ} \mathrm{C}$ ); (2) species with opportunistic calling activity associated with rainfall during the wettest months of the year; (3) winter

Table II. Calling and breeding patterns of 38 anuran species at Serra do Caraça, southeastern Brazil, from October 2001 to September 2002. Classes of abundance of calling males: (1) 1-2, (2) 3-5, (3) 6-10, (4) 11-20, (5) 21-50, (6) more than 50. C indicates not quantified calling activity that occurred outside of the studied sites. Evidence of breeding: ${ }^{a}$ amplectant pair, ${ }^{\mathrm{f}}$ gravid female, ${ }^{\mathrm{s}}$ spawning. $B P$, breeding patterns: Y, species that call year-round or nearly year-round with larger aggregations generally observed in the rainy months; O, species with opportunistic calling activity associated with rainfall during the wettest months of the year; W, winter species; E, explosive breeders with intense calling activity triggered by heavy rains during the rainy season or only in the beginning of the rainy season; S, summer species with variable breeding seasons.

\begin{tabular}{|c|c|c|c|c|c|c|c|c|c|c|c|c|c|}
\hline & Oct & Nov & Dec & Jan & Feb & Mar & Apr & May & Jun & Jul & Aug & Sep & $B P$ \\
\hline Hypsiboas polytaenius & 4 & 4 & 4 & 3 & 3 & $4^{a}$ & 4 & 4 & 3 & 3 & 4 & 3 & $\mathrm{Y}$ \\
\hline Scinax duartei & 4 & 4 & 4 & 1 & 5 & 3 & 4 & 4 & & $\mathrm{C}$ & $\mathrm{C}$ & 3 & $\mathrm{Y}$ \\
\hline Phasmahyla jandaia & 4 & 4 & 4 & 4 & 4 & 3 & 2 & & 1 & 3 & 3 & 4 & $\mathrm{Y}$ \\
\hline Crossodactylus trachystomus & & & 1 & 3 & 3 & 2 & 1 & 1 & $\mathrm{C}$ & $\mathrm{C}$ & 1 & 1 & $\mathrm{Y}$ \\
\hline Eleutherodactylus juipoca & 5 & 6 & 6 & 6 & 5 & 2 & & & & & & 5 & $\mathrm{O}$ \\
\hline Hyalinobatrachium sp. (aff. eurygnathum) & 3 & 4 & 5 & 5 & 4 & 4 & & & & & & & $\mathrm{O}$ \\
\hline Phyllomedusa burmeisteri & $\mathrm{C}$ & $\mathrm{C}$ & $\mathrm{C}$ & & & & & & & & & $\mathrm{C}$ & $\mathrm{O}$ \\
\hline Hyalinobatrachium uranoscopum & & 1 & $4^{\mathrm{a}, \mathrm{s}}$ & 1 & 1 & 1 & & & & & & & $\mathrm{O}$ \\
\hline Leptodactylus bokermanni & & $\mathrm{C}$ & $\mathrm{C}$ & $\mathrm{C}$ & & & & & & & & & $\mathrm{O}$ \\
\hline Eleutherodactylus izecksohni & & $\mathrm{C}$ & 1 & & & & & & & & & & $\mathrm{O}$ \\
\hline Eleutherodactylus sp. (gr. lacteus) & & & 6 & 6 & 2 & 1 & & & & & & 2 & $\mathrm{O}$ \\
\hline Odontophrynus cultripes & & & & $\mathrm{C}$ & $\mathrm{C}$ & & & & & & $\mathrm{C}$ & $\mathrm{C}$ & $\mathrm{O}$ \\
\hline Scinax luizotavioi & 1 & 3 & & & $\mathrm{C}$ & 1 & 3 & 4 & 5 & $6^{\mathrm{a}, \mathrm{s}}$ & 5 & $\mathrm{C}$ & $\mathrm{W}$ \\
\hline Scinax machadoi & & & $-{ }^{f}$ & & & $-{ }^{\mathrm{f}}$ & 2 & 3 & 2 & 2 & $2^{\mathrm{f}}$ & $\mathrm{C}$ & W \\
\hline Scinax sp. 2 (gr. catharinae) & & & & & & & & & 1 & 1 & 2 & & $\mathrm{~W}$ \\
\hline Scinax sp. 3 & $3^{\mathrm{s}}$ & 2 & $\mathrm{C}^{\mathrm{a}}$ & & $\mathrm{C}$ & & & & & & & & $\mathrm{E}$ \\
\hline Dendropsophus seniculus & $\mathrm{C}$ & $\mathrm{C}$ & $\mathrm{C}^{\mathrm{a}}$ & & & & & & & & & $6^{\mathrm{f}, \mathrm{a}}$ & $\mathrm{E}$ \\
\hline Elachistocleis ovalis & & $2^{\mathrm{f}, \mathrm{a}}$ & & & & & & & & & & & $\mathrm{E}$ \\
\hline Proceratophrys boiei & & $\mathrm{C}$ & & & & & & & & & & & $\mathrm{E}$ \\
\hline Leptodactylus jolyi & & & $\mathrm{C}$ & & & & & & & & & 2 & $\mathrm{E}$ \\
\hline Chaunus pombali & & & & & & & & & & $\mathrm{C}$ & $\mathrm{C}$ & $\mathrm{C}^{\mathrm{a}}$ & $\mathrm{E}$ \\
\hline Bokermannohyla martinsi & $3^{\mathrm{f,s}}$ & $3^{\mathrm{s}}$ & 3 & 3 & 2 & $\mathrm{C}$ & $\mathrm{C}$ & $\mathrm{C}$ & & & $C^{f}$ & $3^{\mathrm{f}}$ & $\mathrm{S}$ \\
\hline Dendropsophus minutus & $6^{\mathrm{a}}$ & $6^{\mathrm{a}}$ & 6 & 5 & 3 & 3 & & & & & $\mathrm{C}$ & $6^{\mathrm{a}}$ & S \\
\hline Bokermannohyla nanuzae & 5 & $5^{\mathrm{s}}$ & 4 & 3 & 3 & 2 & & & & & 1 & 1 & $\mathrm{~S}$ \\
\hline Scinax sp.1 (aff. perereca) & $6^{\mathrm{f}, \mathrm{a}}$ & 6 & 3 & 3 & 3 & 3 & & & & & & 5 & $\mathrm{~S}$ \\
\hline Hypsiboas albopunctatus & $\mathrm{C}$ & 2 & & $\mathrm{C}$ & $\mathrm{C}$ & $\mathrm{C}$ & & & & & & & S \\
\hline Scinax squalirostris & 4 & 5 & 6 & 3 & & & & & & & & 5 & S \\
\hline Physalaemus evangelistai & 4 & 5 & 3 & 1 & & & & & & & & 3 & S \\
\hline Physalaemus cuvieri & $4^{\mathrm{f}}$ & $5^{\mathrm{a}, \mathrm{s}}$ & 1 & & & & & & & & & $4^{\mathrm{f}}$ & S \\
\hline Bokermannohyla alvarengai & 2 & & & & & & & & & & $\mathrm{C}$ & 1 & S \\
\hline Leptodactylus ocellatus & $1^{\mathrm{s}}$ & 2 & & & & & & & & & & & S \\
\hline Aplastodiscus arildae & & 3 & 3 & 3 & 3 & 2 & & & & & $\mathrm{C}$ & 1 & $\mathrm{~S}$ \\
\hline Hylodes uai & & 3 & 4 & 3 & 2 & 4 & 3 & 3 & & & & & $\mathrm{~S}$ \\
\hline Hypsiboas faber & & 2 & & 1 & 1 & $\mathrm{C}$ & & & & & & $\mathrm{C}$ & S \\
\hline Bokermannohyla circumdata & & $-\mathrm{f}^{\mathrm{a}}$ & & & $\mathrm{C}$ & 1 & & & & & $-{ }^{\mathrm{f}}$ & & S \\
\hline Physalaemus sp. (aff. olfersii) & & & 4 & 2 & & & & & & & & & S \\
\hline Scinax eurydice & & & $\mathrm{C}$ & & & & & & & & & & $?$ \\
\hline Dendropsophus elegans & & & & 2 & & & & & & & & & $?$ \\
\hline \# species with calling males & 19 & 26 & 25 & 22 & 20 & 18 & 8 & 7 & 6 & 8 & 14 & 23 & \\
\hline $\begin{array}{l}\text { \# species that attained their } \\
\text { maximum class of calling males }\end{array}$ & 8 & 14 & 13 & 8 & 4 & 3 & 1 & 2 & 0 & 1 & 2 & 5 & \\
\hline \# species with evidence of breeding & 6 & 6 & 4 & 0 & 0 & 2 & 0 & 0 & 0 & 1 & 3 & 5 & \\
\hline
\end{tabular}


species (breeding season between April and August); (4) explosive breeders (sensu WELLs, 1977a) with intense calling activity triggered by heavy rains during the rainy season or only in the beginning of the rainy season; in this group, we observed large, ephemerous aggregations of calling males [Dendropsophus seniculus (Cope, 1868), Leptodactylus jolyi Sazima \& Bokerman, 1978, Proceratophrys boiei (Wied-Neuwied, 1824)], active search for females accompanied by intense competition among males and heterospecific amplexes [Elachistocleis ovalis (Schneider, 1799), Scinax sp.3], and multiple amplexes and displacement behaviour [Chaunus pombali (Baldissera, Caramaschi \& Haddad, 2004)]; (5) summer species with longer or shorter breeding seasons [remaining species, except for Dendropsophus elegans (Wied- Neuwied, 1824) and Scinax eurydice (Bokermann, 1968), whose patterns were not clear]; in this group, Hylodes uai Nascimento, Pombal \& Haddad, 2001 called only during the day.

The number of species that called, the number of species that had evidence of breeding, and the number of species that attained their highest classes for the number of calling males are in Fig. 2. The reproductive activity of most species was associated with the rainy season. The number of species with calling males was positively correlated with mean monthly temperature $\left(\rho_{\mathrm{s}}\right.$ $=0.5888, P=0.044)$ and with mean monthly rainfall $\left(\rho_{\mathrm{s}}=\right.$ $0.8561, P=0.00038)$. The number of species that attained their maximum class of calling males was also positively correlated with mean monthly temperature $\left(\rho_{\mathrm{s}}=0.7047, P\right.$ $=0.01049)$ and with mean monthly rainfall $\left(\rho_{\mathrm{s}}=0.8912, P=\right.$ $0.0001)$.

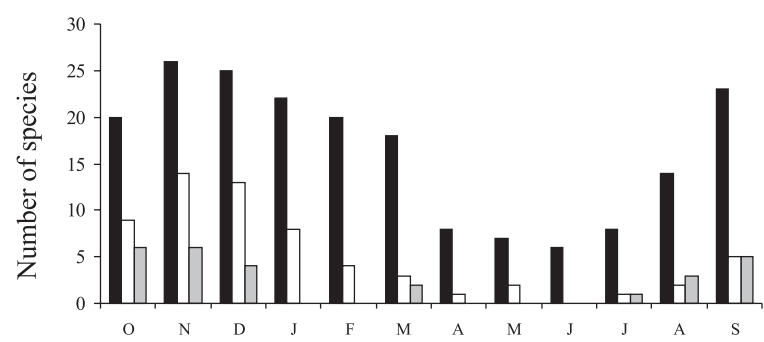

Fig. 2. Number of species with calling males (black), number of species that attained their maximum class of calling males (white), and number of species that had evidence of breeding (gray) between October 2001 and September 2002 at four aquatic sites of Serra do Caraça, Southeastern Brazil.

\section{DISCUSSION}

The anuran fauna of Serra do Caraça is largely dominated by Hylidae and by the former Leptodactylidae (sensu lato) (FROsT et al., 2006), which is typical of other Neotropical sites (CRump, 1974; Duellman, 1978; Aichinger, 1987, CARdoso et al., 1989; HeYer et al., 1990; HADDAD \& SAZIMA, 1992; Rossa-Feres \& JiM, 1994; Bertoluci, 1998; Eterovick \& Sazima, 2000; Bertoluci \& RoDRIGUES, 2002a,b).

The breeding activity of anurans at Serra do Caraça was closely related to the rainy season. More than $80 \%$ of the species were reproductively active exclusively or predominantly during that period. This general pattern corroborates patterns found in seasonal Neotropical areas both in Amazonia (ToFT \& Duellman, 1979; Aichinger, 1987; Hero, 1990; GASCON, 1991; Duellman, 1995) and southeastern Brazil (BERTOLUCI, 1998; ETEROVICK \& SAZIMA, 2000; Bertoluci \& Rodrigues, 2002a). Only four species $(10.5 \%)$ showed calling activity throughout the year or almost throughout the year; similar low proportions of continuous breeders were also found at other Neotropical seasonal sites (see references above). A high proportion of continuous breeders is characteristic of aseasonal environments (CRUMP, 1974).

The year-round activity of Hypsiboas polytaenius at Serra do Caraça agrees with the continuous pattern described for this species at Boracéia, state of São Paulo, another Atlantic rainforest locality of southeastern Brazil, $600 \mathrm{~km}$ southeast of Serra do Caraça, at about $900 \mathrm{~m}$ above sea level (Bertoluci \& Rodrigues, 2002a). The breeding period of Crossodactylus trachystomus at Serra do Caraça agrees with data found for Crossodactylus sp. from another Atlantic rainforest locality of southeastern Brazil, Botucatu, state of São Paulo (RossA-FerES \& JIM, 1994). The breeding period of Scinax duartei (B. Lutz, 1951) at Serra do Caraça was much longer than that found at Serra do Cipó, state of Minas Gerais, another montane meadow locality of Espinhaço Range, southeastern Brazil (EtEROVICK \& SAZIMA, 2000). This could be explained by the less humid climate of Serra do Cipó (around 1,500 mm; GALVÃO \& NIMER, 1965).

About $21 \%$ of the species showed opportunistic calling activity (including diurnal) associated with rainfall in the summer. This group includes the endotrophic species, either nidicolous [Leptodactylus bokermanni (Heyer, 1973)] or with direct development (Eleutherodactylus spp.; Thibaudeau \& Altig, 1999). This pattern was also observed for other species of Leptodactylus ( $L$. marmoratus) and Eleutherodactylus (E. guentheri, E. parvus and E. randorum) at Boracéia (BERTOLUCI \& RODRIGUES, 2002a), suggesting a dependence of these species on high levels of humidity to spawn. Other species that called exclusively or almost exclusively in the rainy days were Hyalinobatrachium sp. (aff. eurygnatum), $H$. uranoscopum (Müller, 1924), Odontophrynus cultripes Reinhardt \& Lütken, 1862 and Phyllomedusa burmeisteri Boulenger, 1882. The reproductive behaviour of $O$. cultripes was similar to that observed in O. americanus at Intervales, state of São Paulo, another Atlantic rainforest locality of southeastern Brazil (BERTOLUCI, 1998). At Serra do Caraça $O$. cultripes did not show the explosive behaviour recorded by $O$. americanus at Intervales, but its calling activity was closely associated with rain falls. The same behaviour was observed for $O$. americanus at Serra do Cipó, where this species reproduced immediately after the filling of temporary puddles (ETEROVICK \& SAZIMA, 2000). Data obtained for this species in Botucatu disagree to this pattern; there its calling activity was associated to the driest, coldest month of the year (ROSSA-FERES \& JIM, 1994). The reproductive period of Phyllomedusa burmeisteri corroborates the pattern found in two other Atlantic forest reserves of southeastern Brazil, the Parque Estadual da Serra do Brigadeiro and the Reserva Particular do Patrimônio Natural Feliciano Miguel Abdala, both also 
located in the state of Minas Gerais (BERTOLuCl et al., 2005). The same pattern was described for $P$. distincta, a very closely related species, in Intervales (BERTOLUCI, 1998).

The winter activity of species of Scinax of the catharinae group [S. luizotavioi (Caramaschi \& Kiteumacher, 1989), S. machadoi (Bokermann \& Sazima, 1973), and Scinax sp. 2] may represent a strategy that reduces interspecific competition in both adult and larval communities by means of temporal partitioning of the habitat. Together with Hypsiboas polytaenius, the winter activity of these species reveals a high tolerance to low temperatures typical of montane anurans (GUIX, 1996). The calling activity of Scinax machadoi restricted to the dryer months of the year must be interpreted with caution because the advertisement call of this species is very weak, at low volume and irregular, and is easily mismatched with the sounds of the rapids in the rainy season. A longer breeding period for this species is suggested by the presence of gravid females in the breeding site in December, March and August. At Serra do Cipó, S. machadoi reproduce almost year-round (BOKERMANN \& SAZIMA, 1973).

The explosive reproduction (WeLls, 1977a, b) observed for some species at Serra do Caraça was already observed in other localities: Botucatu (Elachistocleis ovalis; ROSSA-FERES \& JIM, 1994), Intervales (Dendropsophus seniculus, Proceratophrys boiei; Bertoluci, 1998), Paranapiacaba, state of São Paulo (P. boiei; Pombal, 1997). Chaunus pombali is described as an early season breeder, with both calling and breeding activity starting in the winter and prolonging until the beginning of the spring (Bertoluci, 1998; Bertoluci \& Rodrigues, 2002a).

Summer species with longer or shorter breeding seasons represent $42.1 \%$ of the anuran community. These species showed great variation in both timing and duration of their breeding season. Bokermannohyla alvarengai (Bokermann, 1956) vocalized during the first heavy rains of the rainy season; this pattern contrasts to the observations made at Serra do Cipó, where its calling season was in the mid summer (ETEROVICK \& SAZIMA, 2000). This strategy should be selected to adjust the larval development period to the warmest months of the year, since water and air temperatures at Serra do Caraça (sometimes below $0^{\circ} \mathrm{C}$; pers. obs.) is much lower than those of Serra do Cipó (Eterovick \& SAzima, 2000). For several species, the same pattern observed here was observed in other southeastern Brazilian localities: Boracéia [Hypsiboas albopunctatus (Spix, 1824), Aplastodiscus arildae (Cruz \& Peixoto, 1987 “1985”), Hypsiboas faber (Wied-Neuwied, 1821), Dendropsophus minutus (Peters, 1872), Leptodactylus ocellatus (Linnaeus, 1758), Physalaemus cuvieri Fitzinger, 1826; Bertoluci \& Rodrigues, 2002a], Botucatu ( $H$. albopunctatus, H. faber, D. minutus, L. ocellatus, $P$. cuvieri; RosSA-FERES \& JIM, 1994), Intervales (H. faber, D. minutus, L. ocellatus, P. cuvieri; Bertoluci, 1998), Paranapiacaba (H. faber, D. minutus; PomBal, 1997). The summer activity of Hylodes uai corroborates the pattern found for the closely related Hylodes phyllodes at Boracéia (BERTOluci \& Rodrigues, 2002a). The calling period of Physalaemus sp. (aff. olfersii) was shorter than that found for the closely related $P$. olfersii at Boracéia
(Bertoluci \& Rodrigues, 2002a), Intervales (Bertoluci, 1998) and Paranapiacaba (Pombal, 1997). The activity of Scinax sp.1 (aff. perereca) corroborates the pattern of the closely related $S$. perereca at Paranapiacaba (PomBAL, 1997). Some summer species breed in semipermanent aquatic sites constructing floating foam nests (Leptodactylus ocellatus, Physalaemus spp.) or excavating shallow basins in the mud (Hypsiboas faber).

The positive correlations between the number of species with calling males and the mean monthly temperature and between the number of species that attained their maximum class of calling males and the mean monthly temperature corroborate the idea that low temperatures inhibit anuran breeding activity (BERTOLUCI, 1998; Bertoluci \& Rodrigues, 2002a). The positive correlations of these variables with mean monthly rainfall corroborate the idea that anuran breeding activity at seasonal tropical areas is closely related to the rainy season (Toft \& Duellman, 1979; Aichinger, 1987; Hero, 1990; Gascon, 1991; Duellman, 1995; Bertoluci, 1998; ETEROVICK \& SAZIMA, 2000; BertoluCI \& Rodrigues, 2002a).

Acknowledgements. We thank Luciana B. Nascimento, Renato N. Feio, Patrícia S. Santos, Vanessa K. Verdade, José P. Pombal Jr., and José Cassimiro for help in species identification and discussions; Ana César, Carla Eisemberg, Éder Álvares, Felipe Leite, Francisco Oliveira, and Patrícia S. Santos for help in the field; RPPN - Santuário do Caraça, specially Consuelo Pagannini, Pe. Célio dell'Amore, and Pe. Sebastião for making this work possible. We also thank IBAMA for providing the licenses for collection (numbers 117/2001/MG and 195/2002/MG).

\section{REFERENCES}

Aichinger, M. 1987. Annual activity patterns of anurans in a seasonal Neotropical environment. Oecologia 71(4):583-592.

Bertoluci, J. 1998. Annual patterns of breeding activity in Atlantic Rainforest anurans. Journal of Herpetology 32(4):607-611.

Bertoluci, J. \& Heyer, W. R. 1995. Boracéia update. Froglog 14:2-3.

Bertoluci, J. \& Rodrigues, M. T. 2002a. Seasonal patterns of breeding activity of Atlantic Rainforest anurans at Boracéia, Southeastern Brazil. Amphibia-Reptilia 23(2):161-167. 2002b. Utilização de hábitats reprodutivos e micro-hábitats de vocalização em uma taxocenose de anuros (Amphibia) da Mata Atlântica do sudeste do Brasil. Papéis Avulsos de Zoologia 42(11):287-297.

Bertoluci, J.; Santos, P. S.; Canelas, M. A. S. \& Cassimiro, J. 2005. Phyllomedusa burmeisteri, the Brazilian Common Walking Leaf Frog. Reptilia 39:38-42.

Bevier, C. R. 1997. Breeding activity and chorus tenure of two Neotropical hylid frogs. Herpetologica 53(3):297-311.

Bokermann, W. C. A. \& S Azima, I. 1973. Anfíbios da Serra do Cipó, Minas Gerais, Brazil. 1: Duas espécies novas de Hyla (Anura Hylidae). Revista Brasileira de Biologia 33(3):329-336.

Cardoso, A. J.; Andrade, G. V. \& Haddad, C. F. B. 1989. Distribuição espacial em comunidades de anfíbios (Anura) no Sudeste do Brasil. Revista Brasileira de Biologia 49(1):241-249.

Crump, M. L. 1974. Reproductive strategies in a tropical anuran community. Miscellaneous Publications of the Museum of Natural History of the University of Kansas 61:1-68.

Duellman, W. E. 1978. The biology of an equatorial herpetofauna in Amazonian Ecuador. Miscellaneous Publications of the Museum of Natural History of the University of Kansas 65:1-352.

1995. Temporal fluctuation in abundances of anurans amphibians in a seasonal Amazonian rainforest. Journal of Herpetology 29(1):13-21.

Eterovick, P. C. \& Sazima, I. 2000. Structure of an anuran community in a montane meadow in southeastern Brazil: 
effects of seasonality, habitat, and predation. AmphibiaReptilia 21(4):439-461.

Eterovick, P. C.; Carnaval, A. C. O. Q.; Borges-Nojosa, D. M.; Silvano, D. L.; Segalla, M. V. \& Sazima, I. 2005. Amphibian declines in Brazil: an overview. Biotropica 37(2):166-179.

Frost, D. R.; Grant, T.; Faivovich, J.; Bain, R. H.; Haas, A.; Haddad, C. F. B.; De SÁ, R. O.; Channing, A.; Willinson, M.; Donnellan, S. C.; Raxworthy, C. J.; Campbell, J. A.; Blotto, B. L.; Moler, P.; Drewes, R. C.; Nussbaum, R. A.; Lynch, J. D.; Green, D. M. \& Wheeler, W. C. 2006. The amphibian tree of life. Bulletin of the American Museum of Natural History 297:1-370.

Galvão, M. V. \& Nimer, E. 1965. Clima. In: IBGE. ed. Geografia do Brasil - Grande Região Leste. Rio de Janeiro, IBGE. v.5, p.91-139.

Gascon, C. 1991. Population- and community-level analyses of species occurrences of central Amazonian rainforest tadpoles. Ecology 72(5):1731-1746.

Guix, J. C. 1996. Actividad invernal de anuros en tres sierras del sudeste de Brasil. Boletín de la Asociación Herpetológica Española 7(1):31-34.

Haddad, C. F. B. \& Sazima, I. 1992. Anfíbios anuros da Serra do Japi. In: Morellatto, L. P. C. ed. História Natural da Serra do Japi: ecologia e preservação de uma área florestal no Sudeste do Brasil. Campinas, Editora da Unicamp/ FAPESP. p.188-211.

Hero, J.-M. 1990. An illustrated key to tadpoles occurring in the Central Amazon forest, Manaus, Amazonas, Brazil. Amazoniana 11(2):201-262.

Heyer, W. R.; Rand, A. S.; Cruz, C. A. G. \& Peixoto, O. L. 1988. Decimations, extinctions and colonizations of frog populations in southeast Brazil and their evolutionary implications. Biotropica 20(3):230-235
Heyer, W. R.; Rand, A. S.; Cruz, C. A. G.; Peixoto, O. L. \& Nelson, C. E. 1990. Frogs of Boracéia. Arquivos de Zoologia 31(4):231-410.

Pombal, J. P., JR. 1997. Distribuição espacial e temporal de anuros (Amphibia) em uma poça permanente na Serra de Paranapiacaba, Sudeste do Brasil. Revista Brasileira de Biologia 57(4):583-594.

RitKe, M. E.; B AвB, J. G. \& RitKe, M. K. 1992. Temporal patterns of reproductive activity in the gray treefrog ( $H y l a$ chrysoscelis). Journal of Herpetology 26(1):107-111.

Rossa-Feres, D. C. \& Jim, J. 1994. Distribuição sazonal em comunidades de anfíbios anuros na região de Botucatu, São Paulo. Revista Brasileira de Biologia 54(2):323-334.

Salvador, A. \& Carrascal, L. M. 1990. Reproductive phenology and temporal patterns of mate access in Mediterranean anurans. Journal of Herpetology 24(4):438-441.

Thibaudeau, G. \& Altig, R. 1999. Endotrophic anurans development and evolution. In: McDiarmid, R. W. \& Altig, R. eds. Tadpoles - the biology of anuran larvae. Chicago and London, University of Chicago. p.170-188.

Toft, C. A. \& Duellman, W. E. 1979. Anurans of the lower Rio Llullapichis, Amazonian Peru: a preliminary analyses of community structure. Herpetologica 35(1):71-77.

Wells, K. D. 1977a. The courtship of frogs. In: TAYLOR, D. H. \& Guttman, S. I. eds. The Reproductive Biology of Amphibians. New York and London, Plenum. p.233-262. 1977b. The social behaviour of anuran amphibians. Animal Behaviour 25(3):666-693.

Weygoldt, P. 1989. Changes in the composition of mountain stream frog communities in the Atlantic Mountains of Brazil: frogs as indicators of environmental deteriorations? Studies on Neotropical Fauna and Environment 243(4):249-255.

ZAR, J. H. 1996. Biostatistical Analysis. Upper Saddle River, Prentice Hall. 662p. 